UDC $504.05 ; 626 / 627$

Yurii S. Vlasiuk ${ }^{1}$, Postgraduate student

ORCID ID: 0000-0002-6359-733Xe-mail: y.s.vlasiuk@nuwm.edu.ua

Dmytro V. Stefanyshyn ${ }^{1,2}$, D. S. (Engineering), Professor of Department, Lead researcher ORCID ID: 0000-0002-7620-1613 e-mail: d.v.stefanyshyn@nuwm.edu.ua

${ }^{1}$ National University of Water and Environmental Engineering, Rivne, Ukraine

${ }^{2}$ Institute of Telecommunications and Global Information Space of NASU, Kyiv, Ukraine

\title{
ON SOME CHALLENGES OF ENVIRONMENTAL IMPACT ASSESSMENT OF SMALL HYDROPOWER PLANTS IN UKRAINE
}

\begin{abstract}
One of the pressing problems of today is the greening of nature management, which is recognized as one of the fundamental components of the newest concept of "sustainable" development. The Law of Ukraine "On Environmental Impact Assessment”, adopted in 2017, has opened up new opportunities for environmental review and regulation of potentially hazardous activities related to the use of natural resources, with involvement of the general public in decision-making processes.

According to this Law, hydropower plants on rivers, regardless of their capacity, are also included in the types of planned activities and objects that can have a significant environmental impact and are subject to environmental impact assessment. Thus, at the legislative level, it is recognized that so-called "small hydropower plants" are capable of adversely affecting the environment and should be considered environmentally and socially dangerous until the opposite is established by the results of the environmental expertise.

It is because of the small capacity of hydropower plants in numerous publications of various domestic authors that the idea that small hydropower plants can not adversely affect the environment and are environmentally safe has been formed and continues to be upheld. Due to this, small hydropower has received the status of "green" energy and state supporting in the form of various attenuations, in particular at the expense of "green" tariff. Our analysis of notifications of planned activities that are subject to the environmental impact assessment coming into the Unified Registry for Environmental Impact Assessment and of the environmental impact assessment reports materials shows that private investors are openly abusing these preferences. Notifications of planned activities, environmental impact assessment reports are prepared in a frankly poor and non-professional manner, mostly by persons who are little connected for research or have an opinion on the absolute environmental safety of small hydropower plants. As a result, information provided to the public often turns out to be incomplete, one-sided, distorted, and in some cases, untrue.

The article highlights the most pressing problems encountered during the practical implementation of the Law of Ukraine "On Environmental Impact Assessment" regarding the construction and operation of small hydropower plants, which could be in interest of scientific and engineering communities, officials and the public.
\end{abstract}

Keywords: greening of nature management; ecological safety; small hydropower; small hydropower plants; environmental impact assessment

(C) Yu.S. Vlasiuk, D.V. Stefanyshyn, 2019 


\title{
Ю.С. Власюк ${ }^{1}$, Д.В. Стефанишин ${ }^{1,2}$
}

${ }^{1}$ Національний університет водного господарства та природокористування, м. Рівне, Україна

${ }^{2}$ Інститут телекомунікацій і глобального інформаційного простору НАН України, м. Київ, Україна

\section{ПРО ДЕЯКІ ПРОБЛЕМИ ОЦІНКИ ВПЛИВУ НА ДОВКІЛЛЯ МАЛИХ ГІДРОЕЛЕКТРОСТАНЦЙ В УКРАЇНІ}

\begin{abstract}
Анотація. Однією з нагальних проблем сьогодення $\epsilon$ екологізація природокористування, яку визнано в якості однієї із засадничих складових новітньої концепиії «стійкого» (або «сталого») розвитку. Прийнятий в 2017 р. Закон Украӥни «Про оцінку впливу на довкілля» відкрив нові можливості для проведення екологічної експертизи та регулювання потенційно небезпечної діяльності, пов'язаної з природокористуванням, із залученням в процеси прийняття рішень широкої громадськості.

Згідно з иим Законом до видів планованої діяльності та об'єктів, які можуть мати значний вплив на довкілля та підлягають очіничі впливу на довкілля, віднесено також гідроелектростаниії на річках незалежно від їх потужності. Таким чином, на законодавчому рівні визнано, щео і так звані «малі гідроелектростаниії» здатні негативно впливати на довкілля $і$ мають вважатися екологічно і сочіально небезпечними, допоки протилежне не буде встановлено за результатами екологічної експертизи.
\end{abstract}

Саме через малу потужність гідроустановок в численних публікаціях різних вітчизняних авторів в свій час була сформована і продовжує відстоюватися думка, щцо малі гідроелектростаниії не можуть негативно впливати на довкілля $i$ є екологічно безпечними. Завдяки ирьму мала гідроенергетика отримала статус «зеленої» енергетики $i$ державну підтримку у вигляді всіляких послаблень, зокрема $i$ за рахунок «зеленого» тарифу. Аналіз повідомлень про плановану діяльність, яка підлягає оціниі впливу на довкілля, щุо надходять в Сдиний Реєстр із оиінки впливу на довкілля, та матеріалів звітів з очінки впливу на довкілля показує, що приватні інвестори у свойх планах відверто зловживають наданими ним преференціями. Повідомлення про плановану діяльність, звіти з оцінки впливу на довкілля готуються відверто неякісно та непрофесіонально, здебільшого особами, які або не мають жодного відношення до проблематики досліджень, або дотримуються думки про абсолютну екологічну безпеку об'єктів малої гідроенергетики. В результаті інформаиія, яка надається громадськості, часто виявлясться неповною, односторонньою, перекрученою, а подекуди $i$ такою, щуо жодним чином не відповідає дійсності.

В статті висвітлено найбільш гострі проблеми, щзо виникли по ходу практичної реалізації Закону України «Про оиінку впливу на довкілля» щзодо будівництва та експлуатації малих гідроелектростаниій, на які мають звернути увагу науковиі та інженери, посадовиі та громадськість.

Ключові слова: екологізація природокористування; екологічна безпека; мала гідроенергетика; малі гідроелектростаниіï; оцінка впливу на довкілля

\section{Вступні зауваження}

Однією 3 ключових вимог сьогодення $є$ екологізація («озеленення») природокористування. Згідно з А.Ф. Реймерсом [1], це означає ощадливу, раціональну експлуатацію природних ресурсів, забезпечення умов 
ефективного їх відтворення, мінімізацію екологічних втрат при збереженні соціальної стабільності, життя й здоров'я людей.

Вимога екологізації природокористування в повній мірі знайшла своє відображення і в Конституції нашої держави [2]. Зокрема, згідно зі Статтею 16 Конституції України обов’язком держави є «Забезпечення екологічної безпеки i підтримання екологічної рівноваги на території України ...», згідно зі Статтею 50 «Кожен має право на безпечне для життя і здоров'я довкілля та на відшкодування завданої порушенням цього права шкоди», а відповідно до Статті 66 - «Кожен зобов'язаний не заподіювати шкоду природі, культурній спадщині, відшкодовувати завдані ним збитки».

Екологізація природокористування $є$ і засадничою складовою новітньої концепції «стійкого» (або «сталого») розвитку [3, 4]. Реалізація цієї концепції передбачає подальше зростання економіки при одночасному поліпшенні екологічної ситуації й вирішенні актуальних соціальних проблем. При цьому забезпечення високої якості довкілля, збереження та відтворення кількісних та якісних його показників, підтримання біорізноманіття, охорона унікальних природних комплексів, пам'яток історичної та культурної спадщини тощо при використанні природних ресурсів визнаються такими ж важливими, як i стимулювання економічного розвитку, досягнення високих стандартів ділової активності, соціально-економічного добробуту людей.

3 прийняттям 23 травня 2017 р. Закону України «Про оцінку впливу на довкілля» [5] (далі - Закон про ОВД, Закон), над імплементацією якого у вітчизняне законодавче поле протягом тривалого часу наполегливо працювали вітчизняна екологічна та юридична спільноти [6-9], з'явилася надія [10-14] на можливість поступового розв'язання гострих проблем забезпечення екологічної та соціальної безпеки природокористування в країні в контексті його екологізації на цивілізованому рівні: на основі забезпечення основних конституційних прав людини, за рахунок пошуку та досягнення розумних компромісів між економічним розвитком держави, свободою приватної економічної діяльності та збереженням цінних в екологічному та соціальному відношенні елементів довкілля, з убезпеченням навколишнього середовища від надмірного негативного впливу потенційно небезпечних державних i приватних проектів.

До прийняття Закону про ОВД [5], оцінка впливу діяльності людини на довкілля (навколишнє середовище) в Україні регламентувалася різними правовими актами, постановами та нормативними документами, не тільки численними, але й багато в чому недосконалими і суперечливими. Серед них слід згадати: закони України «Про екологічну експертизу», «Про регулювання містобудівної діяльності», «Про охорону навколишнього природного середовища», постанову Кабінету Міністрів України від 28 серпня 2013 року №808 «Про затвердження переліку видів діяльності та об’ єктів, що становлять підвищену екологічну небезпеку», «Порядок залучення громадськості до обговорення питань щодо прийняття рішень, які можуть впливати на стан довкілля», затверджений постановою Кабінету Міністрів України від 29 червня 2011 року №771, Державні будівельні норми (ДБН) А.2.2-1-2003 «Склад і зміст матеріалів оцінки впливів на навколишнє середовище (ОВНС) при проектуванні і будівництві підприємств, будинків і споруд. Основні положення проектування» та інші нормативно-правові акти [9]. Окрім явного законодавчого «перевантаження» вітчизняної процедури екологічної 
експертизи різними нормативними актами, суттєвим її недоліком було й те, що вона не передбачала вільного доступу громадськості до екологічної інформації, участі громадськості в процесі прийняття рішень, що стосуються планованої діяльності, яка може загрожувати екологічній та соціальній безпеці, а також вільного доступу до правосуддя 3 питань, що стосуються довкілля. Тому, після підписання Україною 25 червня 1998 р. Орхуської конвенції («Конвенція про доступ до інформації, участь громадськості в процесі прийняття рішень та доступ до правосуддя з питань, що стосуються довкілля» [15]), яка займає особливо значиме місце серед міжнародних природоохоронних конвенцій, та іiі ратифікації Верховною Радою 6 липня 1999 р. (Закон України від 06.07.1999 р., №832), Україна набула сумну славу держави, законодавство якої не відповідає міжнародним зобов'язанням, що стосуються доступу до інформації, участі громадськості в процесі прийняття рішень та доступу до правосуддя з питань, що стосуються довкілля (див. також пункт 6 (a) Рішення II/5b Наради Сторін Орхуської Конвенції) [12]. Власне прийняття в 2017 р. Закону про ОВД [5] і мало за мету виправлення цієї ситуації шляхом законодавчого забезпечення в країні максимальної прозорості в усіх питаннях, що стосуються екологічної експертизи діяльності, яка може завдати шкоди довкіллю.

\section{Актуальність проблеми та мета досліджень}

Згідно з Законом [5] оцінку впливу на довкілля (ОВД), за результатами якої приймається рішення про провадження планованої діяльності і надається на це дозвіл (частина 4 статті 3 Закону), проходять не усі проекти, а лише ті, які можуть мати значний вплив на довкілля [14]. Закон про ОВД містить вичерпний перелік видів планованої діяльності та об'єктів, які підлягають ОВД (частини 2 і 3 статті 3 Закону, де в статті 3, частині 3 «Друга категорія видів планованої діяльності та об'єктів, які можуть мати значний вплив на довкілля та підлягають оцінці впливу на довкілля» виділено i «гідроелектростанції на річках незалежно від потужності»).

Таким чином, згідно з прийнятим Законом про ОВД [5], визнано, що і так звані «малі гідроелектростанції» (МГЕС) (в Україні до МГЕС відносять гідроелектростанції потужністю до 10 МВт включно) «можуть мати значний вплив на довкілля» i, відповідно, мають вважатися екологічно і соціально небезпечними, допоки протилежне не буде встановлено за результатами ОВД. Тобто, іншими словами, Законом [5] формально знято будь-які дискусії щодо «абсолютної» безпечності для довкілля та місцевого населення об'єктів малої гідроенергетики, незважаючи на малу потужність гідроустановок.

Проблема в тім, що в численних публікаціях, в тому числі і наукових (див., наприклад, [16-21]), серед авторів яких є як професійні енергетики та гідроенергетики, екологи і гідробіологи, так і різного роду перекваліфіковані 3 інших областей знань «аналітики» та «екологи» подібні до проф. С.С. Попа [19], саме через малу потужність гідроустановок тривалий час в країні формувалася i продовжує відстоюватися думка, що об'єкти малої гідроенергетики в принципі не можуть негативно впливати на довкілля i апріорі мають розглядатися екологічно і соціально безпечними.

При цьому твердження про «екологічність», «нешкідливість» МГЕС формулювалися і продовжують формулюватися на основі формального 
порівняння МГЕС з великими гідроелектростанціями (ГЕС), потужність яких складає більше 10 МВт. При цьому до уваги не беруться річки, на яких ці об'єкти розташовуються. Вважається, що якщо потужність ГЕС не більше 10 МВт, то вона, на думку цих експертів, має бути екологічно безпечною i шкоди довкіллю не завдаватиме, де б іiі не будували, бо вона мала, а якщо, наприклад, іiі потужність складатиме 10,1 МВт - то тоді вже стає потенційно небезпечною і шкоду довкіллю може завдавати, бо вже велика.

Можливо, саме завдяки таким науковим публікаціям [16-21] та іншим подібним аналітичним «дослідженням», практично всі (винятки нам поки що невідомі) фізичні та юридичні особи, які зацікавлені в будівництві об'єктів малої гідроенергетики, в своїх «Повідомленнях про плановану діяльність, яка підлягає оцінці впливу на довкілля» (далі, «Повідомлення») особливо не переймаються обгрунтуванням доцільності планованої діяльності. Більш того, ще до проведення формальної процедури оцінки впливу потенційно небезпечних, згідно з Законом [5], об'єктів, до яких відносяться об'єкти малої гідроенергетики, стверджують про «мінімальність», «незначність» або «повну відсутність» негативного впливу будівництва і експлуатації МГЕС на довкілля (річкову мережу, природні екосистеми, життєдіяльність місцевого населення тощо). В цьому можна пересвідчитися, проаналізувавши численні «Повідомлення про плановану діяльність», пов'язану з проектуванням та будівництвом МГЕС. Ці «Повідомлення» в обов'язковому порядку подаються в Єдиний реєстр із оцінки впливу на довкілля, далі - Реєстр [22], який веде Міністерство екології та природних ресурсів України, і з якими при бажанні легко можна ознайомитись.

На нашу думку, сам факт появи таких тверджень в офіційних документах, які регламентуються Законом [5] і якими є «Повідомлення про плановану діяльність», ще до оцінки впливу на довкілля, може розглядатися не інакше як свідоме введення громадськості в оману. В результаті, при подальшому обговоренні планованої діяльності, громадськість, екологічні активісти тощо втрачають ініціативу, вже самі змушені захищатися від недобросовісних природокористувачів, а не навпаки. Інвестор хоче громаду ощасливити заявленими покращеннями, а якісь екологи підбурюють іiі протестувати i видумують різні перепони. Далі, якщо в «Повідомленні» планована діяльність вже оцінена позитивно з точки зору впливу на довкілля, то важко чекати іншої оцінки в звіті з ОВД. Розробником ОВД, в принципі, може бути будь-хто, зокрема сам інвестор або особа чи організація, які працюють на нього на договірній основі. Тому в звітах з ОВД, $з$ якими теж без проблем можна ознайомитися в Реєстрі [22], скоріше мова йде про оцінку впливу довкілля на об'єкти малої гідроенергетики, а не про оцінку впливу на довкілля. В звітах здебільшого присутня інформація про те, що може зашкодити планованій діяльності, а не про те, яку шкоду вона завдасть.

Серйозним недоліком нового Закону про ОВД [5], на нашу думку, є й те, що він не поширюється на побудовані до його прийняття об'єкти. Слід зазначити, що негативні впливи МГЕС на річки і довкілля можуть проявлятися не лише при їх будівництві чи в перші роки експлуатації.

Мета наших досліджень полягала в аналізі цих та інших, найбільш гострих, на нашу думку, проблем, пов'язаних 3 оцінкою впливу об'єктів малої гідроенергетики в Україні в зв’язку з прийняттям закону про ОВД. 


\section{Викладення основних положень статті}

Перше, що насторожує в «Повідомленнях», що подаються в Реєстр про плани побудови нових МГЕС, це те, що численні приватні структури, задіяні в малій гідроенергетиці в країні, мету здійснення своєї діяльності пов'язують 3 «Національним планом дій з відновлюваної енергетики на період до 2020 р.», затвердженим розпорядженням Кабінету Міністрів України від 01.10.2014 р. №902-p [23], та «Програмою розвитку гідроенергетики на період до 2026 року», схваленою розпорядженням Кабінету Міністрів України від 13.07.2016 p. №552-p. [24]. При цьому, насправді, ця діяльність жодним чином не узгоджується 3 цими планами та програмами, як і з будь-якими іншими державними планами та програмами, зокрема, щодо розвитку водного господарства, охорони і збереження довкілля тощо.

Слід зазначити, що практично всі МГЕС в Україні, а ті, що плануються до будівництва - всі, на відміну від об'єктів великої гідроенергетики, належать приватному бізнесу. Наскільки узгоджуються при цьому суспільні і приватні інтереси - невідомо, адже у державних планах і програмах немає жодної згадки про можливість та доцільність побудови саме цих, цілком конкретних об' єктів малої гідроенергетики, наприклад, в контексті вирішення цілком конкретних соціально-економічних завдань - чи то на державному, чи на місцевому рівнях, 3 відповідним соціально-економічним обгрунтуванням. Тому повноцінно проаналізувати доцільність будівництва кожної заявленої МГЕС в контексті соціально-економічного розвитку місцевої громади, району, області тощо надзвичайно складно.

Дивно, що приватні інвестори в малу гідроенергетику взагалі пов’язують мету приватної планованої діяльності зі «сприянням збільшенню частки виробленої електроенергії із відновлювальних джерел енергії у загальному енергетичному балансі України», а не з отриманням прибутку. В принципі, отримання прибутку від природокористування має бути єдино розумною $\mathrm{i}$ можливою в цьому випадку метою приватного інвестора. Тим більше, що в «Повідомленнях про плановану діяльність» та в звітах з ОВД не аналізується загальний стан малої гідроенергетики в країні, не вказується, які завдання вона здатна вирішувати (окрім, звичайно, прибутків для інвестора) i, в першу чергу, - чи вирішує вона їх на місцевому рівні, адже саме про це опосередковано згадується в Програмі [24]; не вказується, які в неї можуть бути перспективи 3 огляду на загальний стан гідроенергетики в країні [25-34].

Насамперед приватним інвесторам слід зважати на те, що доля малої гідроенергетики в загальному енергобалансі країни не лише є надзвичайно малою, а й такою залишиться, навіть якщо малими гідроелектростанціями будуть забудовані всі вітчизняні річки без винятку. Вже це ставить під сумнів доцільність розвитку малої гідроенергетики в країні. Крім того, приватний бізнес має бути чесним перед суспільством: жодна 3 побудованих чи планованих МГЕС не передбачає вирішення місцевих проблем з електропостачанням. Всі МГЕС приєднуються до об'єднаної енергосистеми 3 метою продажі державі виробленої на них електроенергії за «зеленим» тарифом - в кілька разів вищим, ніж середньозважений тариф в електроенергетиці, і за умов, коли це вигідно власнику, а не суспільству.

Потенційні забудовники малих річок, зокрема і тих річок, що ще збереглися в стані, близькому до природного, і ще не можуть розглядатися як 
антропогенно перетворені чи істотно змінені водні об'єкти [35], обіцяють «покращення», навіть «значне», екологічної ситуації на цих річках завдяки будівництву та експлуатації МГЕС. Це повністю суперечить міжнародній практиці, згідно 3 якою, на таких річках, для їх збереження, будь-яке будівництво не рекомендується або забороняється [35-37]. В результаті простий обиватель підводиться до думки, що якщо екологічна ситуація на річках, де вони планують побудувати i експлуатувати МГЕС, наразі i складається не зовсім добре, то це лише тому, що МГЕС на них ще не побудовано. Має місце свідоме перекручування реальних фактів.

Щоб переконати громадськість, серед соціально-економічних перспектив будівництва МГЕС в «Повідомленнях» та звітах 3 ОВД відзначають $\mathrm{i}$ «безперебійне забезпечення населення екологічно чистою електроенергією», i «вагомий внесок у розвиток як регіональної економіки, так і економіки України в цілому», «залучення значних інвестицій» в місцеву економіку та інші соціально-економічні «покращення». Обіцяють все, що приходить на думку. Наприклад, потенційний забудовник двох МГЕС на р. Латориця (ТОВ «Гідроресурс-Латориця») в «Повідомленнях про плановану діяльність» пообіцяв жителям в м. Мукачеве ще й таке: «ні на одному з етапів» проекту не використовувати «дитячої чи примусової праці».

Місцевим громадам, відкрито чи завуальовано, пропонується безальтернативність планованій діяльності, пов'язаній з будівництвом МГЕС. Так, навіть в якості технічних альтернатив в багатьох «Повідомленнях» та звітах з ОВД замість МГЕС місцеві жителі мають розглядати «будівництво та експлуатацію ТЕС» або «нових атомних енергоблоків» (як, наприклад, для Коростишівської МГЕС, потужністю до 199 кВт, на р. Тетерів, пропонувало ТОВ «Свободна енергія»). I це не поодинокі випадки (див. Реєстр [22]). Місцевий житель, ознайомившись з подібним «Повідомленням про плановану діяльність» чи зі звітом з ОВД, в Реєстрі, який веде державна структура, яка нібито ж відповідає за екологічну безпеку, охорону довкілля, в кращому випадку почуватиметься розгубленим. А раптом ці інвестори справді не проти в його селі, селищі чи в місті побудувати теплову чи атомну електростанцію? Нехай тоді вже буде МГЕС.

Про те, що об'єкти малої гідроенергетики здатні негативно впливати на довкілля, причому як кожен індивідуальний об'єкт окремо, так і в сукупності, і цей вплив може бути значним, в тому числі і в порівнянні з об'єктами великої гідроенергетики, висвітлено в наших попередніх роботах [25-34].

Якщо ж зважати на вагу негативних екологічних та соціальних наслідків в порівнянні зі встановленою потужністю гідроустановок та виробленою електроенергією, питомий негативний вплив на довкілля МГЕС може бути не меншим, а можливо навіть і більшим, ніж питомий негативний вплив на довкілля від великих ГЕС [34].

Звичайно, приватні інвестиції у вітчизняну малу гідроенергетику не $є$ злочином. Як і не є злочином зацікавленість приватних інвесторів в прибутку, в тому числі і за рахунок «зеленого» тарифу. Але всі оті екологічні та соціальні «покращення», про які з таким пафосом згадується в «Повідомленнях про плановану діяльність», насправді нічого не варті, в порівнянні з тією шкодою, яка завдається довкіллю від будівництва та експлуатації МГЕС на малих річках. 
Особливо це стосується тих «інвесторів», кому «не соромно» за вже побудовані ними МГЕС, кому в свій час вдалося уникнути процедури ОВД та провести вбивчі для малих річок проекти без широкого розголосу, ще й отримати за це державні нагороди й визнання. Наприклад, зовсім не соромно за свої МГЕС пану I. В. Тинному - засновнику і співвласнику енергетичного холдингу «Гідроенергоінвест-Акванова» [38]. Компанія володіє 29 міні ГЕС, загальна потужність яких складає 30 мВт; в тому числі і на річці Случ, яка в останні роки катастрофічно потерпає від маловоддя в межень і стрімко деградує практично на всій своїй протяжності (рис. 1).

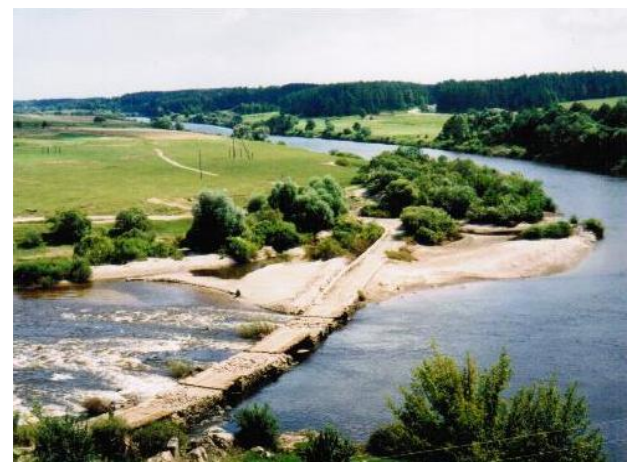

a)

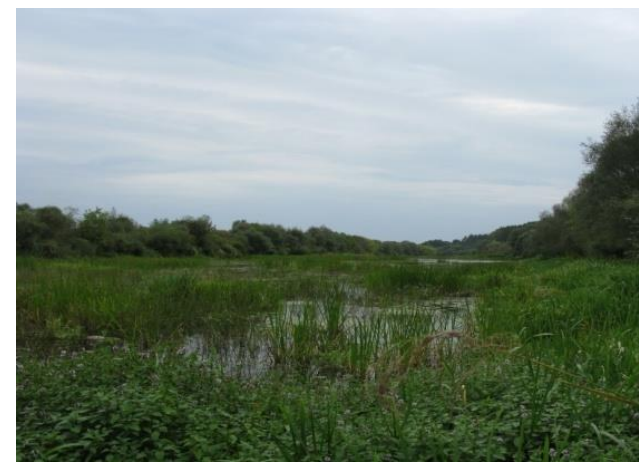

б)

Рис. 1 - Ріка Случ, літня межінь, біля с. Більчаки (Рівненська обл.):

a) початок 2000-х pp.; б) 2018 p.
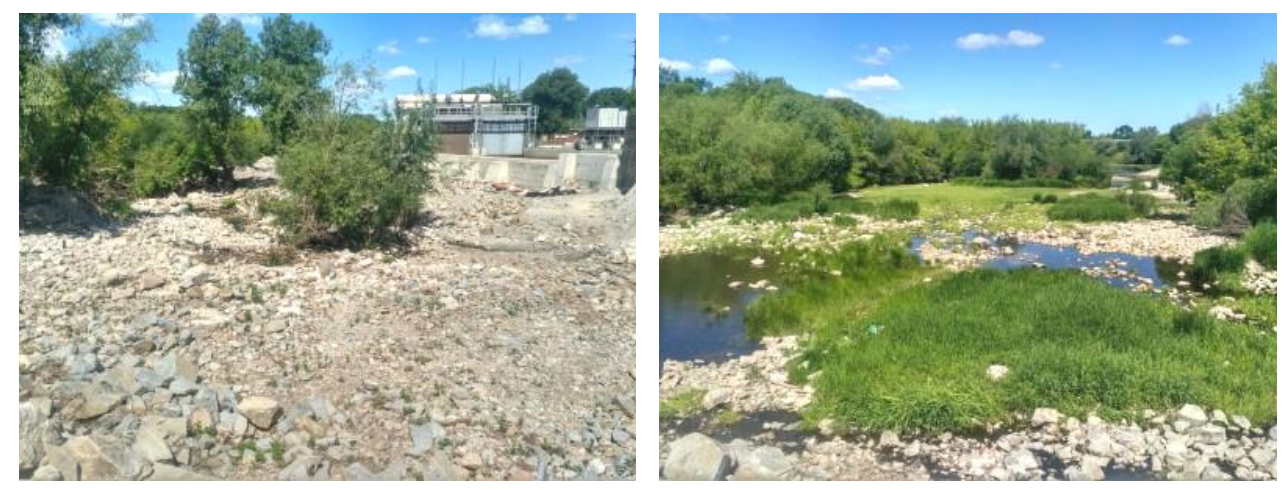

Рис. 2 - Нижній б'єф греблі Чижівської МГЕС (с. Чижівка, Житомирська обл.). Річка Случ, травень 2017 р. Фото: Петро Тєстов [39]

Зазвичай дії власників МГЕС в екстремальних екологічних ситуаціях, спричинених маловоддям, не є конструктивними. Вони до кінця намагаються боротися за прибуток, відстоюючи приватні інтереси. Наприклад, у серпні 2017 р. проблема маловоддя на р. Случ нижче за течією від м. НовоградВолинський у нижньому б'єфі відновленої в 2015 р. Чижівської МГЕС набула таких масштабів [39] (див. також вище рис. 2), що для вирішення проблеми обезводнення русла була утворена спеціальна комісія 3 представників всіх гілок районної влади. I іï рішенням було не спрацювання водосховища 3 вимушеним тимчасовим призупиненням роботи МГЕС, для збереження річки. На прохання ТОВ «Гідроенергоінвест-Акванова» «тимчасово» була зменшена так звана «санітарна» витрата: з 2,39 м³/с до 1,5 м³/c. 


\section{Прикінцеві зауваження та висновки}

Інвестори в малу гідроенергетику мають визнавати, що їхня діяльність безпосередньо пов'язана 3 природокористуванням і несе загрози довкіллю. При цьому при будівництві та експлуатації МГЕС використовуються різні природні ресурси, і не лише водні і територіальні, а й такі, можливо, ефемерні для пана Тинного, як, наприклад, естетичні, рекреаційні тощо. Вплив МГЕС на довкілля може бути як прямим, так і опосередкованим. При цьому різні природні ресурси, що використовуються, не є повністю відновлюваними. Річки, їх екосистеми, природні ландшафти тощо, в тому числі і завдяки малій гідроенергетиці, стрімко деградують, зменшується водність річок в межінь, відбуваються незворотні гідроморфологічні зміни, зникає біорізноманіття.

Маємо також визнати, що єдине, що по суті відрізняє вітчизняну малу гідроенергетику від великої в контексті обгрунтування доцільності будівництва та експлуатації гідроенергетичних об'єктів 3 врахуванням їх впливу на довкілля, це те, що мала гідроенергетика, на відміну від великої, має серйозну державну підтримку у вигляді всіляких послаблень, зокрема i за рахунок «зеленого» тарифу. Багато в чому ця підтримка недалекоглядна, необгрунтована та навіть шкідлива для вітчизняної гідроенергетичної галузі, на що ми вказували, наприклад, в [25, 27, 32]. Ця підтримка в принципі заважає прийняттю раціональних рішень щодо природокористування в малій гідроенергетиці, їх екологізації, оскільки ці рішення виходять зі співставлення очікуваних прибутків та затрат приватного інвестора, а не грунтуються на співставленні суспільної вигоди та суспільної шкоди планованої діяльності. Маємо також зважати і на те, що приватні інвестори не є зацікавленими і не мають такими бути у фінансуванні неприбуткових, неефективних для себе сфер, в тому числі і «комплексного використання водних ресурсів» тощо, як того вимагають чинні норми [40], і будь-які «сторонні» для себе затрати намагатимуться мінімізувати, а отримувані вигоди, зокрема і від «зеленого» тарифу, - максимізувати. Тому і пропонуються проекти МГЕС лише з одним агрегатом, зі встановленою потужністю станцій до 199 кВт чи до 999 кВт, 3 деривацією, в яку відводиться практично вся вода з русла в межінь, з вигідним для забудовника територіальним розміщенням (безпосередньо в населеному пункті, близько до автомобільних доріг, ліній електропередач) тощо.

Суспільний інтерес при цьому, незважаючи на посилання на «Національний план дій» [23], «Програму розвитку гідроенергетики» [24] тощо, належно не враховується. Він просто ігнорується. Якщо, наприклад, для великої гідроенергетики, яка хоча і має порівняно невелику частку в загальному балансі (до 9\%) електроенергетики країни, але відіграє важливу системоутворюючу функцію в іiі об'єднаній енергосистемі (ОЕС), і навіть 3 врахуванням серйозної шкоди, яку завдали і завдають довкіллю великі ГЕС та ГАЕС, як кожна окремо, так і в сукупності, на даний момент соціальноекономічного розвитку країни можна знайти достатньо вагомих аргументів для ii. виправдання, 3 врахуванням різних ризиків та факторів, що мають загальносуспільне значення, то мала гідроенергетика не лише має вкрай мізерну питому вагу в балансі вітчизняної ОЕС (близько 0,15\%), а й принципово не впливає i не зможе впливати в майбутньому на умови енергозабезпечення країни, в тому числі і окремих 㣙 регіонів. Суспільне значення малої гідроенергетики в Україні, зокрема і через несприятливі для 
розвитку гідроенергетичної галузі природні умови [25-34], вкрай мале, а в майбутньому лише зменшуватиметься, а суспільна шкода вже значна, в тому числі і завдяки «зеленому» тарифу, а в майбутньому може ще й збільшитися. 3 часом може постати проблема ліквідації багатьох таких об'єктів на наших річках, з важко прогнозованими наслідками. Таким чином, перше питання, яке має виникати при плануванні будівництва нової МГЕС, особливо на річці, на якій подібне будівництво ще не провадилось, це питання не можливості, а доцільності такого природокористування, його суспільної виправданості в порівнянні з можливою суспільною шкодою.

\section{СПИСОК ЛІТЕРАТУРИ}

1. Реймерс Н.Ф. Природопользование: Словарь-справочник. Москва : Мысль, 1990. $637 \mathrm{c}$.

2. Конституція України: прийнята на п’ятій сесії ВР України 28 червня 1996 р. Відомості ВР України. 1996. № 30. URL : https://zakon.rada.gov.ua/laws/show/ 254\%D0\%BA/96-\%D0\%B2\%D1\%80.

3. Згуровський М.З. Сталий розвиток $у$ глобальному і регіональному вимірах: аналіз за даними 2005 р. Київ : Політехніка, 2006. 84 с.

4. Стефанишин Д.В., Стефанишина-Гаврилюк Ю.Д. Оптимізація структури інвестиційного портфеля в природокористуванні на підставі попарного порівняння альтернатив 3 врахуванням ризику невикористаних можливостей. Системні дослідження та інформаџійні технології. 2017. №3. С. 107-116.

5. Про оцінку впливу на довкілля: Закон України № 2059-VIII від 23.05.2017. Офіиійний вісник України. 2017. №50. С. 5. Відомості Верховної Ради (ВВР), 2017, № 29, ст. 315. URL : http://zakon.rada.gov.ua/laws/show/2059-19.

6. Позняк Е. Оцінка впливу на довкілля і участь громадськості в ній у формі громадської екологічної експертизи: міжнародно-правові та національно-правові аспекти. Вісник Київського національного університету ім. Тараса Шевченка. Юридичні науки. 74-76. 2007. С. 126-129.

7. Андрусевич А.О. Оцінка впливу на довкілля в Україні: вирішення проблеми по-європейськи. Аналітичний документ. 2011. 18 с.

8. Оцінка впливу на довкілля та участь громадськості: аналітичний порівняльний огляд європейського й українського законодавства та рекомендації щодо впровадження європейських стандартів в Україні [за наук. ред. Д. Скрильнікова та Є. Алексєєвої]. Львів : ЕПЛ. 2013. 96 с.

9. Чайковська Н. Правові аспекти здійснення оцінки впливу на довкілля. Науковий часопис Національної академії прокуратури України. 2017. №4. С. 214-223.

10. Самойленко Ю. Удосконалення системи оцінки впливу на довкілля в контексті екологічного супроводу проектів. Економічний дискурс. Міжнародний науковий журнал. 2017. Вип. 3. С. 109-117.

11. Алексєєва Є. Оцінка впливу на довкілля: можливості для громадськості (посібник) [за заг. ред. О. Кравченко]. Львів : Видавництво «Компанія «Манускрипт». 2017. 36 с. 12. Сидор В. Оцінка впливу на довкілля: Закон працює, проблеми залишаються. Підприємництво, господарство і право. Екологічне право. 2018. №6. С. 142-146.

13. Ландау Ю.О., Сташук І.В. Значення гідроенергетики в розвитку ОЕС України відповідно до НЕС-2035 і екологічні виклики. Гідроенергетика України. 1-2. 2018. C. 3-6.

14. Алексєєва Є. Популярний коментар до Закону України «Про оцінку впливу на довкілля». За заг. ред. О. Кравченко. Львів : Видавництво «Компанія «Манускрипт». $2018.60 \mathrm{c}$. 
15. Конвенція про доступ до інформації, участь громадськості в процесі прийняття рішень та доступ до правосуддя 3 питань, що стосуються довкілля (Орхуська конвенція). URL : https://zakon.rada.gov.ua/laws/show/994_015.

16. Ландау Ю.А. Основные тенденции развития гидроэнергетики Украины. Техногенна безпека. Наукові праці. 2012. Том 53. Вип. 40. С. 82-86.

17. Розвиток теплоенергетики та гідроенергетики / за ред. В.М. Клименко, Ю.О. Ландау, І.Я. Сігал. 2013. 399 с. URL: http://energetika.in.ua/ ua/books/book-3/part2/section-2/2-8.

18. Шкробот М.В. Сучасний стан та перспективи розвитку гідроелектроенергетики України. Бізнес-навігатор. №1 (27). 2012. С. 66-70.

19. Поп С.С. Гідроенергетичний потенціал Закарпаття: стан та перспективи його раціонального використання. Науковий вісник Ужгородського ун-ту. Серія: Географія. Землеустрій. Природокористування. Ужгород : Говерла. Вип. 2. 2013. С. 98-111.

20. Васько П.Ф., Васько В.П., Ібрагімова М.Р. Мала гідроенергетика в структурі електроенергетичної галузі України. Відновлювана енергетика. 2015. № 3. С. 53-61.

21. Васько П.Ф., Мороз А.В. Потенціал використання гідроенергетичних ресурсів основних малих річок України. Відновлювана енергетика. 2016. № 3. С. 50-56.

22. Оцінка впливу на довкілля. Сдиний реєстр. URL: http://eia.menr.gov.ua/search.

23. Національний план дій 3 відновлюваної енергетики на період до 2020 р.: Затверджено розпорядженням Кабінету Міністрів України від 01.10.2014 p. №902-р. URL: https://zakon.rada.gov.ua/laws/show/902-2014-\%D1\%80/stru.

24.Програма розвитку гідроенергетики на період до 2026 року : Схвалено розпорядженням КМ України від 13.07. 2016 p. № 552-p. URL: http://zakon2.rada.gov.ua/laws/show/552-2016-\%D1\%80\#n7.

25. Стефанишин Д. В. Соціально-екологічні проблеми відновлення та модернізації малих гідроелектростанцій в Україні. Гідроенергетика України. № 1-2. 2015. С. 18-22.

26. Атаєв С.В., Стефанишин Д.В. Прогнозування змін гідролого-морфологічних характеристик річок при техніко-економічному обгрунтуванні проектів відновлення малих гідроелектростанцій. Екологічна безпека та природокористування. Зб. наук. праць. Вип. 17. Київ : ІТГІП НАНУ, КНУБА. 2015. С. 57-64.

27. Стефанишин Д.В., Атаєв С.В. Перспективи відновлення малих гідроелектростанцій в Україні в контексті екологічно безпечного природокористування. Екологічна безпека та природокористування. Зб. наук. праць. Вип. 18. Київ : ІТГІП НАНУ, КНУБА. 2015. C. $5-11$.

28. Стефанишин Д.В., Бенатов Д.Э. О перспективах развития гидроэнергетического комплекса Украины в контексте экологизации природопользования. Международный молодежный научный экологический форум «Экобалтика» (24-27 августа, 2017, Гродно, Республика Беларусь): Сборник трудов - Гродно: Изд-во Гродн. Гос. Аграрн. Ун-та, 2017. С. 100-108.

29. Стефанишин Д. В. Про перспективи розвитку вітчизняної гідроенергетики в контексті планів будівництва каскаду гідроелектростанцій у Дністровському каньйоні. Екологічна безпека та природокористування. Зб. наук. праць. Вип. 23. Київ : ІТГІП НАНУ, КНУБА. 2017. С. 5-19.

30. Стефанишин Д.В. Про ризики гідроенергетичного будівництва у Дністровському каньйоні. Математичне моделювання в економіці. 2017. № 1-2. С. 172-183.

31. Stefanyshyn D. On peculiarities of hydropower development in the world and in Ukraine. Екологічна безпека та природокористування. Зб. наук. праць. Вип. 25. Київ : КНУБА, ІТГІП НАНУ. 2018. С. 12-23.

32. Власюк Ю.С., Стефанишин Д.В. Про проблеми та перспективи малої гідроенергетики в Україні. Математичне моделювання в економіці. № 1 (10). 2018. C. $126-138$.

33. Стефанишин Д.В. Деякі критичні зауваження та пропозиції щодо підтримки сталого розвитку гідроенергетики в Україні. Гідроенергетика Украӥни. № 1-2. 2018. C. 6-12. 
34. Стефанишин Д.В., Власюк Ю.С. До питання порівняльного аналізу водноенергетичних характеристик малих і великих гідроелектростанцій України у складі гідровузлів з водосховищами. Математичне моделювання в економіці. № 2. 2018. С. 71-83.

35. Identification and Designation of Heavily Modified and Artificial Water Bodies. CIS Working Group 2.2. 10 December 2002. 11 p. URL : http://www.wrrl-info.de/docs/ HMWBpolicysummary101202.pdf.

36. Securing Water for Ecosystems and Human Well-being: The Importance of Environmental Flows. Copyright (C2009, Swedish Water House (SWH). P. 52. URL: https://cmsdata. iucn.org/downloads/securing_water_for_ecosystems_and_human_well_being.pdf.

37. Managing Water under Uncertainty and Risk. The United nations World Water Development Report 4. Vol. 1. Published by UNESCO. 2012. 407 p. URL : http://www.unesco.org/new/fileadmin/MULTIMEDIA/HQ/SC/pdf/WWDR4\%20Volume\% 201-Managing\%20Water\%20under\%20Uncertainty\%20and\%20Risk.pdf.

38. Ігор Владиславович Тинний. URL : https://znaj.ua/dossier/58-igor-vladislavovich-tinniy. 39. Тєстов П. Каскад ставків замість річки Случ? Екологія, право, людина. URL : http://epl.org.ua/announces/kaskad-stavkiv-zamist-richky-sluch/.

40. ДБН В.2.4-3:2010. Гідротехнічні, енергетичні та меліоративні системи і споруди, підземні гірничі виробки. Гідротехнічні споруди. Основні положення. Київ : Міністерство регіонального розвитку та будівництва України, 2010. 37 с.

Стаття надійшла до редакиії 03.07.2019 і прийнята до друку після рецензування 02.08.2019

\section{REFERENCES (TRANSLATED AND TRANSLITERATED)}

1. Reimers, N.F. (1990). Natural Resources Use: Dictionary-Reference. Moscow: Dumka, 637 p. (In Russian).

2. Constitution of Ukraine: Adopted at the Fifth Session of the Verkhovna Rada of Ukraine on June 28, 1996. 1996. No. 30. Retrieved from https://zakon.rada.gov.ua/laws/show/ 254\%D0\%BA/96-\%D0\%B2\%D1\%80. (in Ukrainian).

3. Zgurovsky, M.Z. (2006). Sustainable Development in Global and Regional Dimensions: An Analysis According to 2005. Kyiv: Polytechnica, 84 p. (in Ukrainian).

4. Stefanyshyn, D.V., Stefanyshyna-Gavryliuk, Yu.D. (2017). Optimizing the structure of the investment portfolio in environmental management based on a pair-wise comparison of alternatives taking into account the risk of unused opportunities. System Research and Information Technologies, №3, 107-116. (in Ukrainian).

5. On Environmental Impact Assessment: Law of Ukraine No. 2059-VIII of 23 May 2017 Official Bulletin of Ukraine. (2017). №50. P. 5. Verkhovna Rada (BBR) Bulletin, No. 29, Art. 315. Retrieved from http://zakon.rada.gov.ua/laws/show/2059-19. (in Ukrainian).

6. Poznyak, E. (2007). Environmental Impact Assessment and Public Participation in the Form of Public Environmental Assessment: International Legal and National Legal Aspects. Bulletin of the Kyiv National University after Taras Shevchenko. Law sciences. 74-76, 126129. (in Ukrainian).

7. Andrusevich, A.O. (2011). Environmental Impact Assessment in Ukraine: Addressing the Problem in Europe. Analytical document, 18 p. (in Ukrainian).

8. Environmental Impact Assessment and Public Participation: An Analytical Comparative Review of European and Ukrainian Legislation and Recommendations for the Implementation of European Standards in Ukraine. (2013). [for Science ed. D. Skrylnikov and E. Alekseeva], Lviv: EPL, 96 p. (in Ukrainian).

9. Tchaikovska, N. (2017). Legal aspects of environmental impact assessment. Scientific journal of the National Academy of Public Prosecutor of Ukraine, №4, 214-223. (in Ukrainian). 10. Samoilenko, Yu. (2017). Improvement of the environmental impact assessment system in the context of environmental support of projects. Economic discourse. International scientific journal, Vol. 3, 109-117. (in Ukrainian). 
11. Alekseeva, E. (2017). Environmental Impact Assessment: Opportunities for the Public (Handbook) [for Science ed. O. Kravchenko]. Lviv: Manuscript Company Publishing House, 36 p. (in Ukrainian).

12. Sidor, V. (2018). Environmental Impact Assessment: The law works, problems remain. Entrepreneurship, economy and law. Environmental law, №6, 142-146. (in Ukrainian).

13. Landau, Yu.O., Stashuk I.V. (2018). The importance of hydropower in the development of the Ukrainian UES in accordance with NES-2035 and environmental challenges. Hydropower of Ukraine, 1-2, 3-6. (in Ukrainian).

14. Alekseeva, E. (2018). A popular commentary on the Law of Ukraine "On Environmental Impact Assessment". For the title. ed. O. Kravchenko. Lviv: Manuscript Company Publishing House, 60 p. (in Ukrainian).

15. Convention on Access to Information, Public Participation in Decision-Making and Access to Justice in Environmental Matters (Aarhus Convention). Retrieved from https://zakon.rada.gov.ua/laws/show/994_015. (in Ukrainian).

16. Landau, Yu.A. (2012). The main trends in the development of hydropower in Ukraine. Technogenic safety. Scientific works, Volume 53, Issue 40, 82-86. (In Russian).

17. Development of heat power engineering and hydropower. (2013). Baseev, Ye. T., Bileka, B. D., Vasiliev, Ye. P., et al .; Science ed. Klymenko, V. M., Landau, Yu. O., Sigal, I. Ya. 399 p. Retrieved from http://energetika.in.ua/ua/books/book-3/part-2/section-2/2-8. (in Ukrainian).

18. Strobot, M.V. (2012). The current state and prospects of development of hydroelectric power in Ukraine. Business navigator, No. 1 (27), 66-70. (in Ukrainian).

19. Pop, S.S. (2013). Hydropower potential of Transcarpathia: state and prospects of its rational use. Scientific Bulletin of Uzhgorod Univ. Series: Geography. Land management. Nature management. Uzhgorod: Hoverla, No. 2, 98-111. (in Ukrainian).

20. Vasko, P.F., Vasko, V.P., Ibrahimova, M.R. (2015). Small hydropower in the structure of the electricity sector of Ukraine. Renewable energy, № 3, 53-61. (in Ukrainian).

21. Vasko, P.F., Moroz, A.V. (2016). Potential of utilization of hydropower resources of the main small rivers of Ukraine. Renewable energy, № 3, 50-56. (in Ukrainian).

22. Environmental Impact Assessment. Unified registry. Retrieved from http://eia.menr.gov.ua/search. (in Ukrainian).

23. National Renewable Energy Action Plan for 2020: Approved by the Decree of the Cabinet of Ministers of Ukraine dated 01.10.2014 № 902-p. Retrieved from https://zakon.rada.gov.ua/laws/show/902-2014-\%D1\%80/stru. (in Ukrainian).

24. Hydropower development program for the period up to 2026. (2016). Approved by the order of the Cabinet of Ministers of Ukraine from 13.07.2016. № 552-r. Retrieved from http://zakon2.rada.gov.ua/laws/show/552-2016-\%D1\%80\#n7. (in Ukrainian).

25. Stefanyshyn, D.V. (2015). Socio-ecological problems of renewal and modernization of small hydropower plants in Ukraine. Hydropower of Ukraine, № 1-2, 18-22. (in Ukrainian). 26. Atayev, S.V., Stefanyshyn, D.V. (2015). Prediction of changes in hydrological and morphological characteristics of rivers in the feasibility study of small hydroelectric rehabilitation projects. Environmental safety and natural resources. Coll. Sciences. works. No. 17. Kyiv: ITGIP of NASU, KNUBA, 57-64. (in Ukrainian).

27. Atayev, S.V., Stefanyshyn, D.V. (2015). Prospects for restoration of small hydropower plants in Ukraine in the context of environmentally friendly environmental management.

Environmental safety and natural resources. Coll. Sciences. works. No. 18. Kyiv: ITGIP of NASU, KNUBA, 5-11. (in Ukrainian).

28. Stefanyshyn, D.V., Benatov, D.E. (2017). On the prospects for the development of the hydropower complex of Ukraine in the context of environmental management. International Youth Scientific Ecological Forum "Ecobaltics" (August 24-27, 2017, Grodno, Republic of Belarus): Proceedings - Grodno: Grodn Publishing House. Gos. Agrarian. Univ., 100-108. (In Russian). 
29. Stefanyshyn, D.V. (2017). On the prospects for the development of domestic hydropower in the context of plans for the construction of a cascade of hydroelectric power stations in the Dniester Canyon. Environmental safety and natural resources. Collection of scientific works. Issue 23 (№ 1-2). Kyiv : ITGIP NASU, KNUCA, P. 5-19. (in Ukrainian).

30. Stefanyshyn, D.V. (2017). On the risks of hydropower construction in the Dniester canyon. Mathematical modeling in economy. № 1-2, P. 172-183. (in Ukrainian).

31. Stefanyshyn, D.V. (2018). On peculiarities of hydropower development in the world and in Ukraine. Environmental safety and natural resources, Issue 25 (№ 1), Kyiv, KNUBA, ITGIP of NASU, 12-23.

32. Vlasyuk, Yu.S., Stefanyshyn, D.V. (2018). On problems and prospects of small hydropower engineering in Ukraine. Mathematical Modeling in Economy, №1, 2018, 126138. (in Ukrainian).

33. Stefanyshyn, D.V. (2018). Some critical remarks and suggestions for supporting the sustainable development of hydropower in Ukraine. Hydropower of Ukraine, № 1-2, 6-12. (in Ukrainian).

34. Stefanyshyn, D.V., Vlasyuk, Yu.S. (2018). To the issue of comparative analysis of waterenergy characteristics of small and large hydroelectric power plants of Ukraine being parts of waterworks with reservoirs. Mathematical Modeling in Economy, №2, 71-83. (in Ukrainian).

35. Identification and Designation of Heavily Modified and Artificial Water Bodies. CIS Working Group 2.2. 10 December 2002. 11 p. Retrieved from http://www.wrrl-info.de/docs/ HMWBpolicysummary101202.pdf.

36. Securing Water for Ecosystems and Human Well-being: The Importance of Environmental Flows. Copyright (C2009, Swedish Water House (SWH). P. 52. Retrieved from https://cmsdata.iucn.org/downloads/securing_water_for_ecosystems_and_human_ well_being.pdf.

37. Managing Water under Uncertainty and Risk. The United nations World Water Development Report 4. Vol. 1. Published by UNESCO. 2012. 407 p. Retrieved from http://www.unesco.org/new/fileadmin/MULTIMEDIA/HQ/SC/pdf/WWDR4\%20Volume\% 201-Managing\%20Water\%20under\%20Uncertainty\%20and\%20Risk.pdf.

38. Igor Tinny. Retrieved from https://znaj.ua/dossier/58-igor-vladislavovich-tinniy. (in Ukrainian).

39. Testov, P. Cascade of ponds instead of the river Sluch? Ecology, law, man. Retrieved from http://epl.org.ua/announces/kaskad-stavkiv-zamist-richky-sluch/. (in Ukrainian).

40. DBN B.2.4-3: 2010. Hydrotechnical, energy and reclamation systems and structures, underground mining. Waterworks. Substantive provisions. (2010). Kyiv: Ministry of Regional Development and Construction of Ukraine, 37 p. (in Ukrainian).

The article was received 03.07.2019 and was accepted after revision 02.08.2019

\section{Власюк Юрій Степанович}

аспірант Національного університету водного господарства та природокористування Адреса робоча: 33028 Україна, м. Рівне, вул. Соборна, 11

e-mail: y.s.vlasiuk@nuwm.edu.ua

ORCID ID: https://orcid.org/0000-0002-6359-733X

\section{Стефанишин Дмитро Володимирович}

доктор технічних наук, провідний науковий співробітник Інституту телекомунікацій і глобального інформаційного простору НАНУ, професор кафедри гідротехнічного будівництва та гідравліки Національного університету водного господарства та природокористування

Адреса робоча: 33028 Україна, м. Рівне, вул. Соборна, 11

e-mail: d.v.stefanyshyn@nuwm.edu.ua

ORCID: https://orcid.org/0000-0002-7620-1613 